\title{
Immersion Duration Effect of Purple Leaf Extract (Graptophllum Pictum) on DSSC
}

\section{GUSTI NGURAH NITYA SANTHIARSA ${ }^{1}$, KOMANG ALIT KUMARA JAYA ${ }^{2}$}

\author{
${ }^{1}$ Mechanical Engineering, Faculty of Engineering, Udayana University, Jimbaran, Bali, \\ 80361 , Indonesia \\ ${ }^{2}$ Master Student at Study Program of Master in Mechanical Engineering, Udayana \\ University, Denpasar, Bali, 80361, Indonesia \\ Email : nitya_santhiarsa@unud.ac.id
}

Received 28 Mei 2021 | Revised 20 Juni 2021 | Accepted 22 Juni 2021

\begin{abstract}
ABSTRAK
Salah satu sumber energi terbarukan yang dapat digunakan sebagai energi alternatif adalah energi matahari. Teknologi sel surya generasi ke-3 adalah Dye Sensitized Solar Cell (DSSC) yang dapat mengonversi sinar matahari menjadi listrik. Daun ungu merupakan daun yang tersebar di Indonesia yang juga merupakan daun yang ekonomis. Pada penelitian ini ekstrak pucuk daun ungu digunakan sebagai pewarna sensitizer yang diekstraksi dengan alkohol 96\% dengan rasio campuran 20 gram pucuk daun ungu yang telah ditumbuk hingga halus dengan alkohol $50 \mathrm{ml}$, kemudian dilakukan perendaman dengan variasi perendaman 12, 24, dan 36 jam. Tujuan penelitian ini adalah untuk mengetahui pengaruh waktu perendaman terhadap tegangan yang dihasilkan oleh DSSC. Hasil arus tertinggi diperoleh pada variasi perendaman 36 jam sebesar 0,8 $\mu$ A. Perendaman selama 12 jam sebesar 0,6 4 A dan perendaman 24 jam sebesar 0,7 $\mu A$.
\end{abstract}

Kata kunci: DSSC, daun ungu, sel surya, lama perendaman.

\begin{abstract}
One of the renewable energy sources that can be used as alternative energy is solar energy. The 3rd generation solar cell technology is Dye Sensitive Solar Cell (DSSC) which can convert sunlight into electricity. Purple leaves are leaves that are scattered in Indonesia which are also economical leaves. In this study, purple leaf shoot extract was used as a sensitizer dye extracted with $96 \%$ alcohol with a mixture ratio of 20 grams of purple leaf shoots that had been ground until smooth with $50 \mathrm{ml}$ alcohol, then soaking was carried out with immersion variations of 12, 24, and 36 hours. The purpose of this study was to determine the effect of immersion time on the stress generated by the DSSC. The highest current results were obtained in the 36 hours immersion variation of $0.8 \mu \mathrm{A}$. Immersion for 12 hours was $0.6 \mu \mathrm{A}$ and immersion for 24 hours was $0.7 \mu \mathrm{A}$.
\end{abstract}

Keywords: DSSC, purple leaf, solar cell, immersion duration. 


\section{INTRODUCTION}

This decade, soaring demand for energy and concern for the environment have prompted intensive exploration to switch to renewable energy. One of the renewable energy sources that is feasible to use is solar energy which is a clean energy source with enormous potential. In addition, the effort to convert sunlight into electrical energy is the most promising effort to store and utilize solar energy, which refers to the development of large-sized solar cells (Wang et al., 2021). With the advancement of technology in the last decade, solar energy has been developed to be transmitted to various public domestic housing. The efficient power supply for large-scale solar energy devices has also been implemented in photovoltaic (PV) technology. This effort is very useful in reducing the energy crisis and environmental pollution (Kong et al., 2020).

All photovoltaic devices and semiconductor devices have a working principle based on the photoelectric effect. Extensive research on photovoltaics (PV) to date has resulted in three generations of solar cells. The first-generation is silicon solar cells and creates the secondgeneration is thin film solar cells (Bennett et al., 2020). DSSC (dye sensitized solar cell) is a photoelectrochemical device that can convert sunlight into electrical energy. The main parts of a dye sensitized solar cell are nanocrystalline titanium dioxide $\left(\mathrm{TiO}_{2}\right)$, an electrolyte containing iodide / triiodide ( $\mathrm{I}^{-} / \mathrm{I}_{3}$-), a dye molecule and a counting electrode which serves as a catalyst for electron regeneration. Dye sensitizers have a very important role in the process of absorbing sunlight to be converted into electrical energy. The dye absorption spectrum is a parameter that can increase the efficiency of the DSSC and also the barrier that encourages electron injection into the $\mathrm{TiO}_{2}$ band to increase the conversion efficiency of the DSSC (Syafinar et al., 2015).

Previous research conducted the development of the dye sensitized solar cells from natural red (extracted from red spinach) and green DSSC (sun spinach). In accordance with the research that has been done, the results of the efficiency of DSSC cells based on red and green dyes are $0.531 \%$ and $0.466 \%$. DSSC has been sensitized with a combination of natural colors such as green and red dyes in order to increase the efficiency of DSSC cells (Kabir et al., 2019). Manufacture of Dye Sensitized Solar Cells (DSSC) from natural dyes such as pandan leaves, turmeric roots, and also black rice seeds that have been dissolved with ethanol. The volume ratio used to make mixed dyes is $1: 1$ as sensitizers to DSSC. The method used to grow a thin $\mathrm{TiO}_{2}$ layer is the doctor's knife method. Characterization of the UV-Vis spectrophotometer was carried out on the dye solution to observe the wavelengths absorbed by the dye and calculate the dye gap energy. From the calculation, the energy gap dye is 1.387-1.777 eV. Meanwhile, from the characterization of voltage current (I-V), the greatest efficiency of single dye was $0.056 \%$ from turmeric dye and the greatest efficiency of dye mixture was $0.207 \%$ from dye mixed with black rice and turmeric (Dahyunir et al., 2016).

Purple leaf plant is a type of plant whose existence is spread almost all over Indonesia, easy to obtain, easy to cultivate and not a leaf of high economic value. Purple leaf plants are very easy to grow anywhere because they do not know the growing season, as shown in Figure 1. 


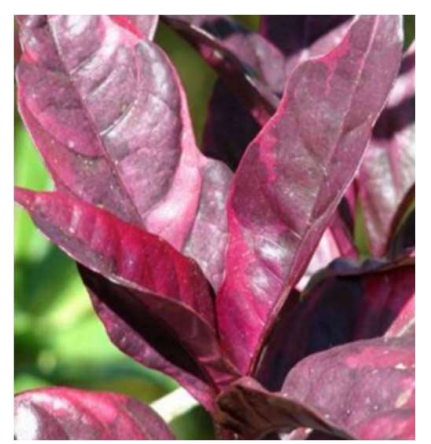

Figure 1. Purple Leaf

(Hardeli et al., 2019) Research on red spinach as an organic dye which has a long soaking time of 24 hours, is a reference that in addition to fruit and flowers, leaves can also be used as a dye sensitizer, but the Malabar spinach and red spinach is a food item that has high economic value. In this study, purple leaves which have low economic value and are easily cultivated use the same goal of being able to produce the electrical voltage as expected and not using food as a dye sensitizer.

\subsection{Solar Cell}

A solar cell is an electronic device that uses photovoltaic phenomena to convert sunlight into electrical energy as shown in Figure 2. The smallest part of a solar cell that can generate electricity is the p-n relationship. When the photon hits the $p-n$ relationship, the atoms in the $\mathrm{n}$ region will absorb the photon, then an electron will be released and after that free electrons will be created. Types of solar cell panels: Polycrystalline (Poly-crystalline) type solar panels, which have a random crystal arrangement. To be able to produce electric power that is equivalent to the monocrystalline type, the polycrystalline type requires a larger surface area and in cloudy weather it can also generate electrical energy. Monocrystalline type (Monocrystalline) is a type of solar panel that has the highest level of efficiency compared to other types of solar panels. This type produces the highest unit area electric power and its efficiency is up to $15 \%$. As for the weaknesses of this type of solar panel, it is not optimal when it is in an area with less sunlight, the efficiency of this type of solar panel will decrease in cloudy weather conditions (Sagita \& Sembodo, 2014).

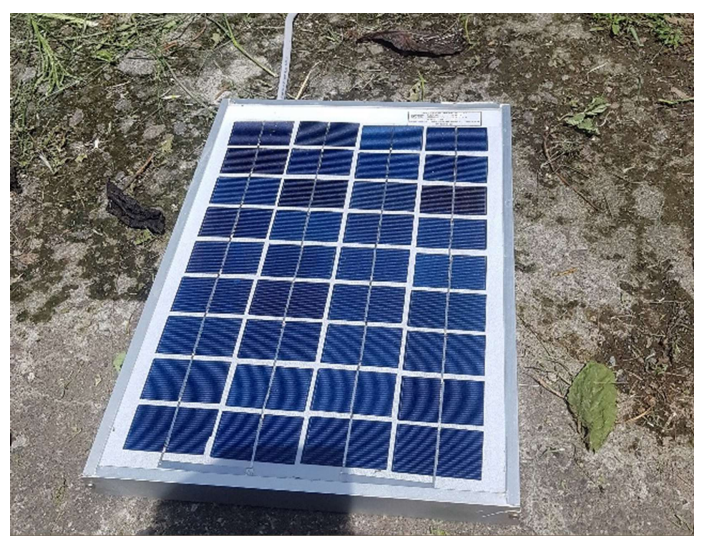

Figure 2. Solar Cell Device

\subsection{Dye Sensitized Solar Cell (DSSC)}

Dye Sensitized Solar Cell (DSSC), is a photoelectrochemical-based solar cell that was first discovered by Professor Michael Gratzel (1991) which has become a topic of intensive research by researchers around the world. DSSC is also called the first breakthrough in solar cell 
technology since silicon solar cells. Although the efficiency of DSSC is still lower than the efficiency of silicon solar cells, the manufacture of DSSC is more environmentally friendly, inexpensive, and the material is easily obtained from nature when compared to silicon solar cells. DSSC has several components such as color-absorbing anocrystalline semiconductor electrodes, electrodes containing iodide ions, electrodes containing triiodide ions, and counting electrodes. The most important role of sensitizers is in absorbing sunlight and converting solar energy to electrical energy. The highest efficiency of DSSC was found in Ru Complex N719 which reached $11-12 \%$. However, the dye from the Ruthenium Complex is a synthetic dye which is quite expensive. While natural dyes can be extracted from parts of plants such as leaves, flowers and fruit. The dye functions as an absorber of solar radiation and a wide-gap semiconductor such as (Titanium Dioxide) $\mathrm{TiO}_{2}$ as a charge carrier. Pigments with a wide electronic absorption character in the visible light region of the sunlight spectrum will theoretically absorb more solar radiation and are good sensitizers (Irwan et al., 2016).

In previous research, Dye Sensitized Solar Cell (DSSC) technology was applied as a greenhouse shading tool, in which DSSC can produce a specific spectrum of light color penetration when it accumulates electricity. In addition, greenhouse plants can absorb light with wavelengths between 400 and $700 \mathrm{~nm}$ (PAR) to carry out photosynthesis and growth (Lu et al., 2020). (Andargie \& Worku, 2016) Conducted research on the manufacture of Dye Sensitized Solar Cells (DSSC) using natural light dyes. Where is the natural dye used from the extract of Acanthus sennii chiovenda flowers and Euphorbia cotinifolia leaves. In the preparation of the DSSC, the solid electrolyte is sandwiched between the working electrode (photoanode) and the counting electrode (FTO glass coated with PEDOT). A study was conducted to review the potential of the DSSC technology and its effectiveness as a shade greenhouse. For an in-depth understanding of the uniqueness and superiority of this technology, it is thoroughly reviewed. Comparisons have been made to conventional PV, where the DSSC technology is more specific in manipulating solar radiation through the optimal photosensitizer option (Roslan et al., 2018). Research from (Ossai et al., 2021) the manufacture of co-sensitizers with dye extracts from the raw material of carica papaya fruit and also from black cherries with different concentration ratio volume. There is also research that makes dye sensitized solar cells (DSSC) from new nanocomposites consisting of the perovskite graphene compound $\mathrm{La}_{2} \mathrm{CrFeW}_{6}$, using a simple hydrothermal technique (Oh et al., 2021).

\subsection{Purple Leaf (Graptophyllum Pictum)}

Purple plants are one type of plant that is used by the community to treat hemorrhoids, ulcers, and wounds. The part of the purple plant that is most used is the leaf part. The benefits of this purple plant are due to the content of its secondary metabolite compounds. Physically, the appearance can be seen from the color on the leaves, which is purple. The purple color is one of the colors of the phenol group (anthocyanin). This is reinforced by the results of research on the content of secondary metabolites possessed by the leaves in the form of a group of phenol derivative compounds (anthocyanins, leukoanthocyanins, flavonoids, and tannins) (Reny, 2018).

\section{EXPERIMENTAL METHOD}

\subsection{Method and Procedure}

The first process of making the extraction of purple leaf shoots is by preparing tools and materials, then the purple leaves are finely ground using a mortar and weighed so that a weight of 20 grams is obtained for each solvent at various immersion times (12, 24, 36 hours). The buds of purple leaves that have been mashed and weighed are then mixed with a solvent (alcohol) each for each variation of $50 \mathrm{ml}$. After each of the three solvents was mixed with the

$$
\text { ELKOMIKA - } 870
$$


buds of purple leaves that have been refined, then allowed to stand with a variation of soaking time $(12,24,36$ hours) in a closed room. Each of the three extracts was filtered using filter paper which later the three extracts will be used as natural dyes for dye sensitized solar cell (DSSC) which had previously been tested for absorbance of the extract with a wavelength range between $200-800 \mathrm{~nm}$ on a UV-Vis spectrophotometer. The research flowchart can be seen in Figure 3.

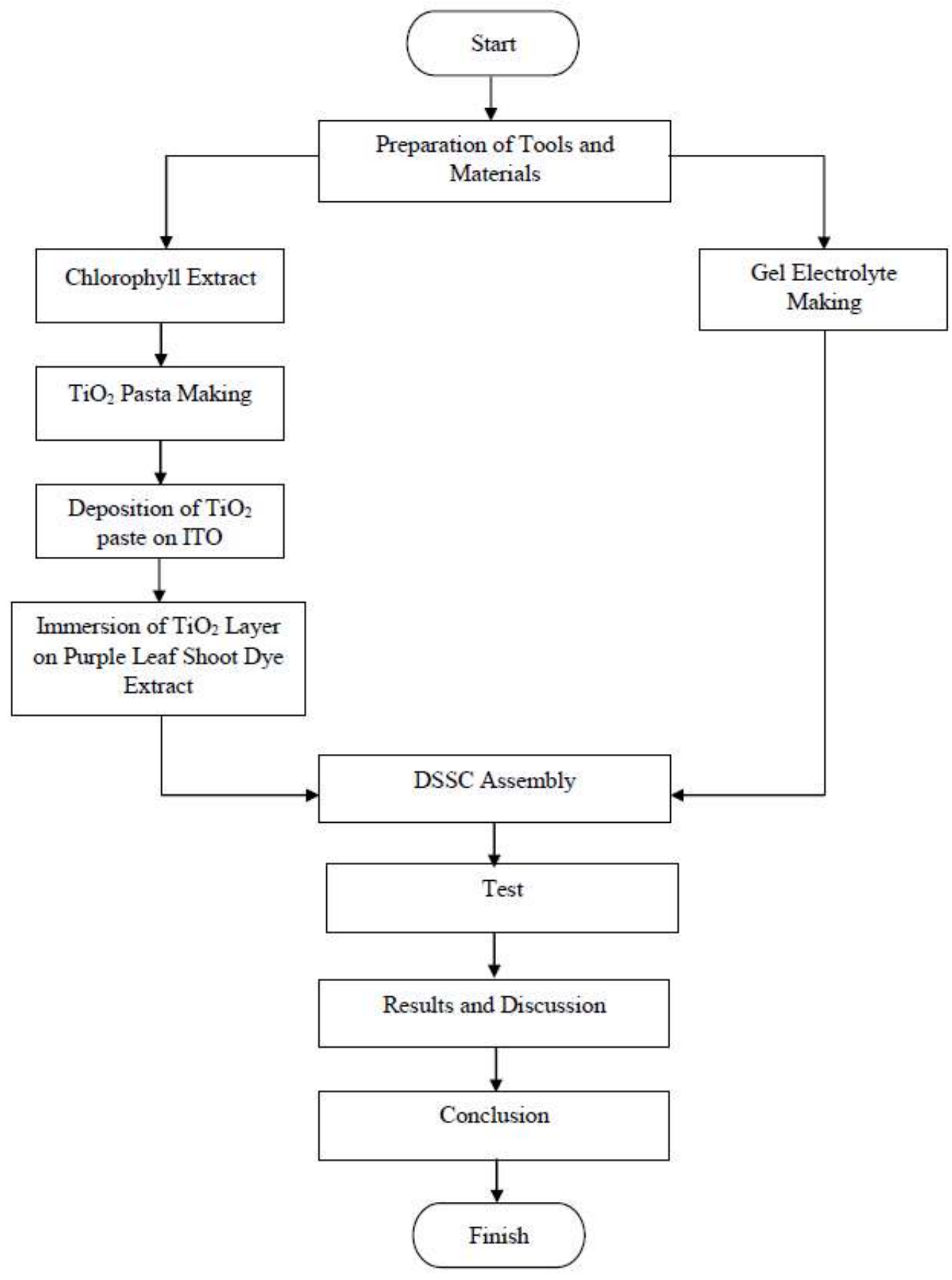

Figure 3. Research Flowchart 
Making Dye Sensitized Solar Cell (DSSC) sandwiches starts from the preparation of materials (extraction, ITO glass, $\mathrm{TiO}_{2}$ nanopores, electrolytes, 8B pencils) and other supporting materials. Starting from making $\mathrm{TiO}_{2}$ paste by mixing $5 \mathrm{gr} \mathrm{TiO} 2$ with $1 \mathrm{gram}$ polyvinyl alcohol (PVA) then stirring at $80^{\circ} \mathrm{C}$ and crushed with mortar. $\mathrm{TiO}_{2}$ paste is then deposited over the area determined with the help of scotch tape measuring $2 \mathrm{~cm} \times 2 \mathrm{~cm}$ on the surface of the ITO glass with the doctor blade method with the help of a stirring rod (spatula) to flatten the $\mathrm{TiO}_{2}$ paste, then leave it for about 10 minutes, after which it is heated on top surface of the hot plate to $300^{\circ} \mathrm{C}$ for about 20 minutes as shown in Figure 4.

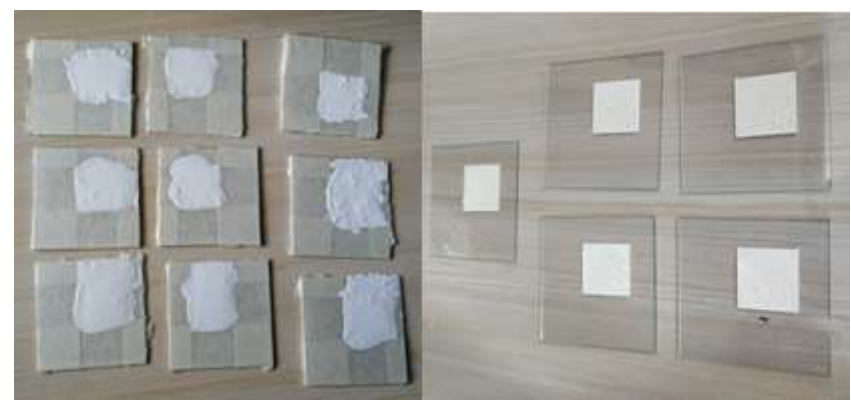

Figure 4. $\mathrm{TiO}_{2}$ Paste Deposition Process

$\mathrm{TiO}_{2}$ layer that has been made with a surface area of $2 \mathrm{~cm} \times 2 \mathrm{~cm}$ is then soaked in purple leaf shoot extract, soaking is done for 24 hours. Electrolytes are made from a mixture of potassium iodide (KI) $6 \mathrm{gr}$ with iodine solution $5 \% 3 \mathrm{ml}$ which is then stirred for 20 minutes then stored in a tightly closed bottle, the initial step of making gel phase electrolytes is to dissolve the polymer material PEG $10002.5 \mathrm{gr}$ with chloroform solvent $5 \mathrm{ml}$ is stirred for 20 minutes at $85^{\circ} \mathrm{C}$, then the finished electrolyte gel is then stored in a tightly closed container. The catalyst uses an 8B pencil shaded on the surface of the ITO glass with a surface area of $2 \mathrm{~cm} \times 2 \mathrm{~cm}$, then is heated using a candle flame to obtain a carbon layer and is heated again on a hot plate to $300^{\circ} \mathrm{C}$ for 20 minutes so that the carbon layer adheres perfectly to the ITO conductive glass and is not easy to fade. The process of making catalyst can be shown in Figure 5.

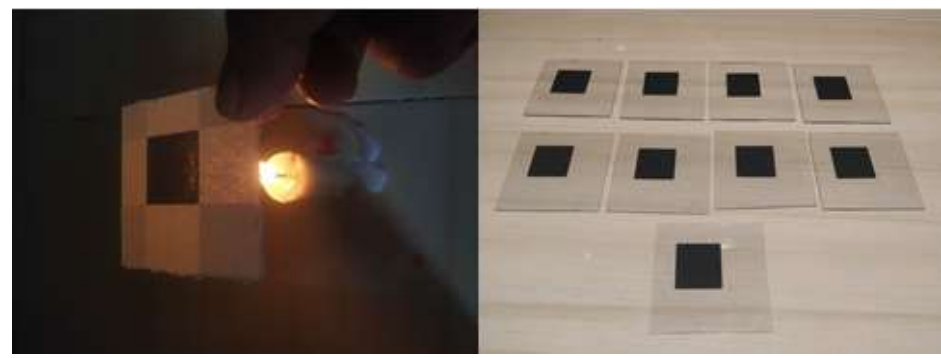

Figure 5. The Process of Making Catalyst 


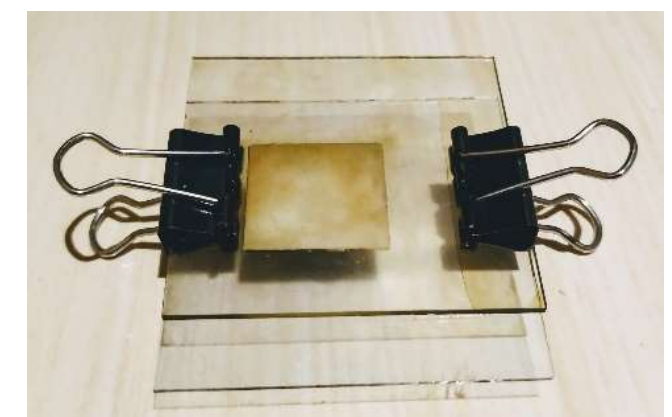

Figure 6. Dye Sensitized Solar Cell (DSSC) Prototype

After the catalyst is complete, the electrolyte is filled in the specified area then the dye sensitized solar cell (DSSC) is assembled until the prototype Dye Sensitized Solar Cell (DSSC) is ready for testing as shown in Figure 6 . After the DSSC testing process, then proceed to the results and discussion steps. Then the final step is at the conclusion stage and the research is completed.

\section{RESULT AND DISCUSSION}

\subsection{Spectrophotometer UV-Vis}

The results of absorbance testing of purple leaf shoot extract with variations in immersion length (12, 24, 36 hours) with alcohol solvents (96\%) were tested using a UV-Vis spectrophotometer in the wavelength range of $200-800 \mathrm{~nm}$ can be shown in the Figure 7. In Figure 7, the variation of the 12 hours immersion length extract of purple leaf shoots has the highest peak at a wavelength of $666 \mathrm{~nm}$ with an absorbance peak value of 1.8 with the complementary color in the wavelength range being bluish green.

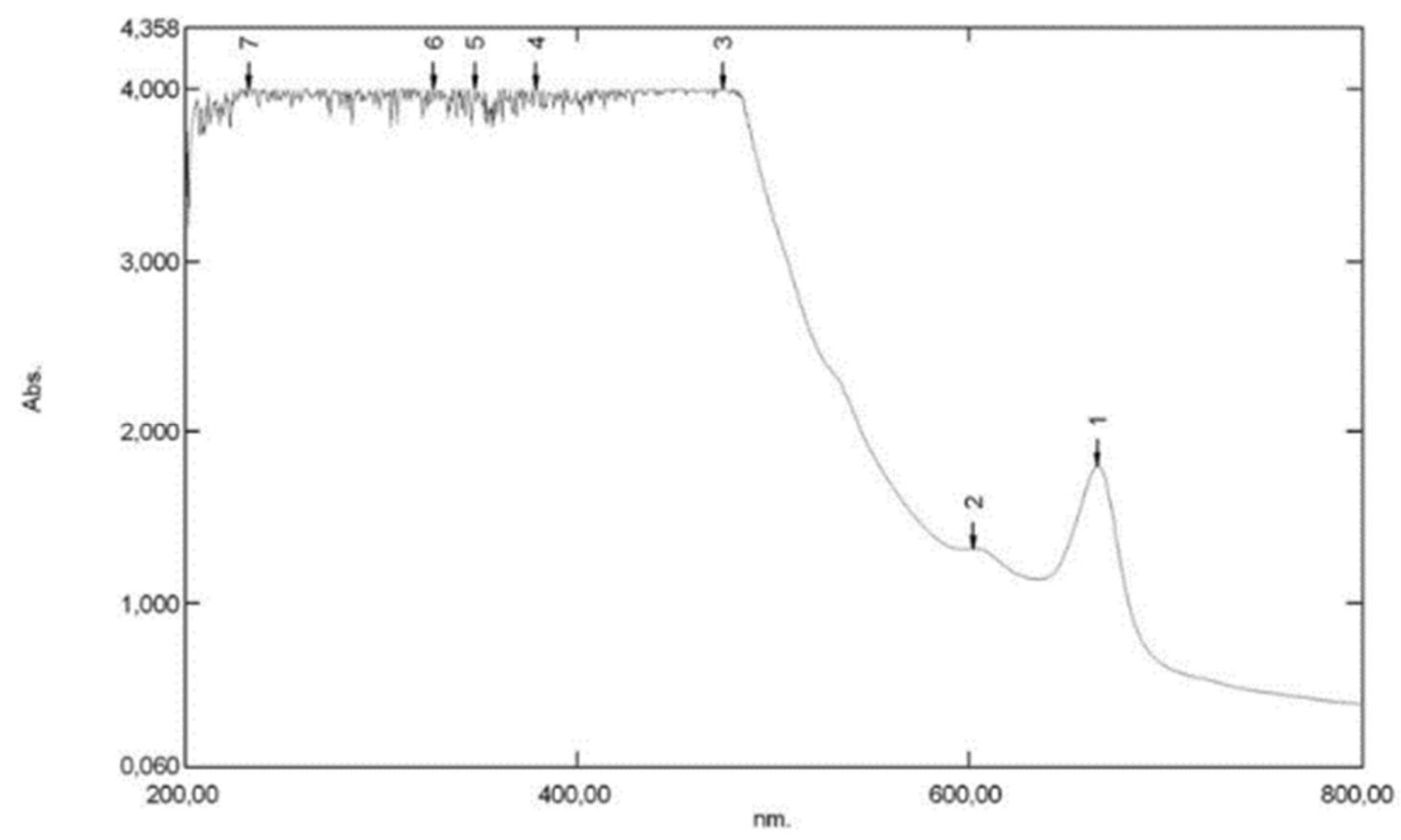

Figure 7. Absorbance for 12 hours 
Variation of 24 hour immersion in Figure 8 below can be seen from the results of the UV-Vis graph of purple leaf shoot extract there is the highest peak at a wavelength of $665 \mathrm{~nm}$ with an absorbance peak value of 2.2 which has a higher value when compared to the 12 hours immersion variation.

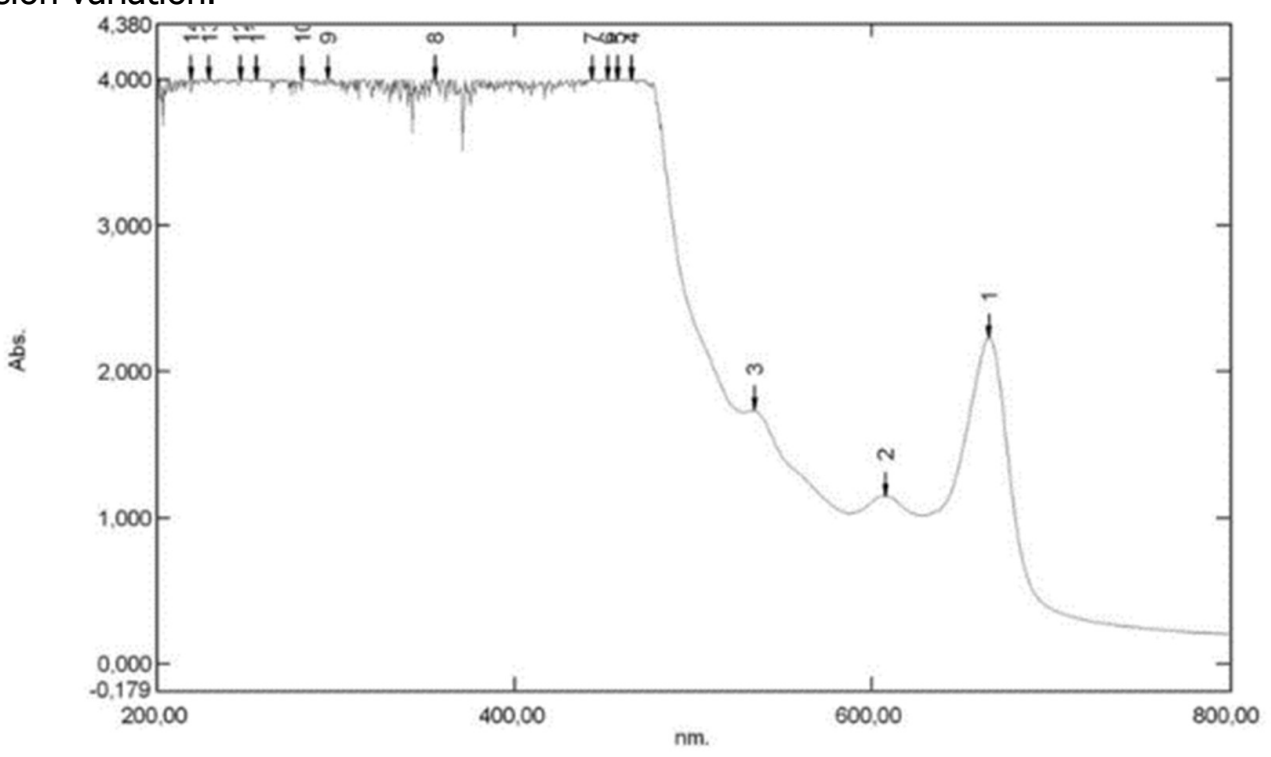

Figure 8. Absorbance for 24 hours

The variation of immersion duration of 36 hours seen in Figure 9 is the highest absorbance value when compared with the variation of immersion duration of 12 hours and 24 hours. The highest absorbance value obtained from the 36 hours immersion length variation was 2.6 in the wavelength range of $666 \mathrm{~nm}$.

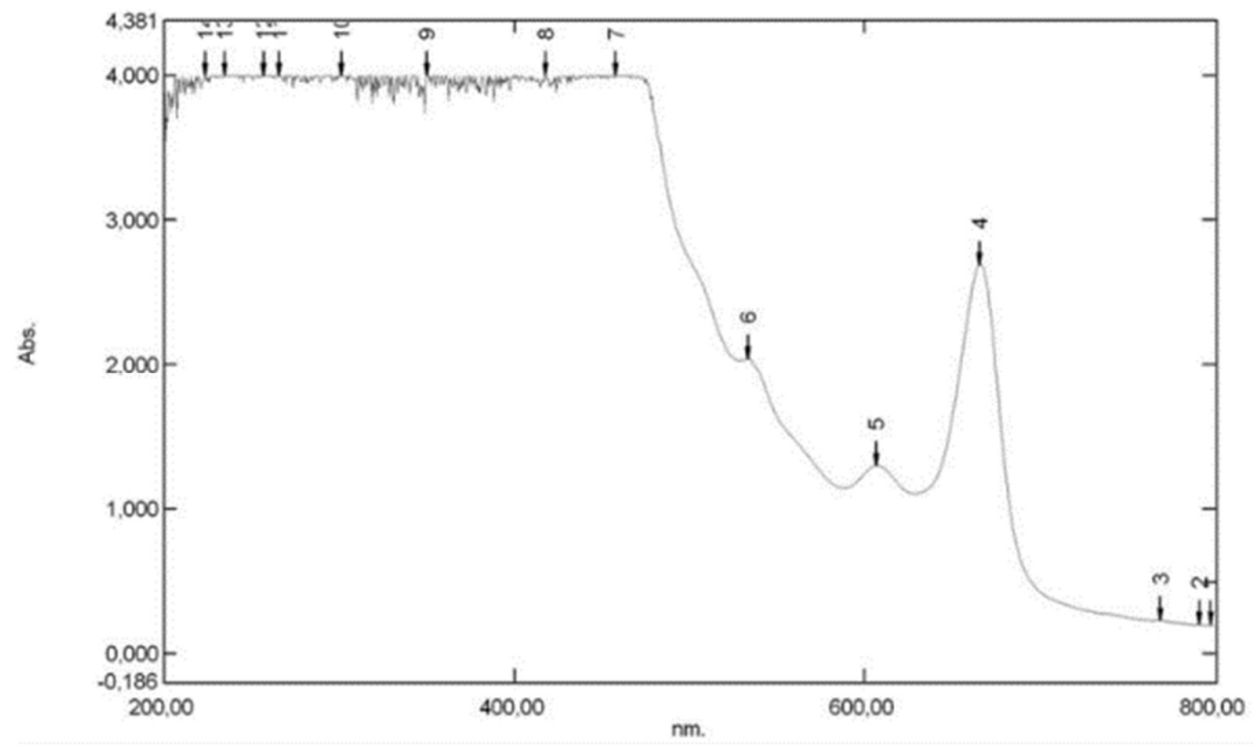

Figure 9. Absorbance for $\mathbf{3 6}$ hours

In this research, the peak absorbance or maximum absorption of the three variations of immersion time $(12,24$ and 36 hours) was obtained in the wavelength range of $665-666 \mathrm{~nm}$ where complementary colors or colors seen in the wavelength range are colors bluish green. 


\subsection{Dye Sensitized Solar Cell (DSSC)}

The results of all the data obtained, it can be ascertained that the variation of the immersion duration of the 36 hours purple leaf extract which has the highest current value when compared with the three variations. The lowest current value is the variation of 12 hours immersion, 24 hours has a value between 12 hours and 36 hours immersion variation. In Figure 10 below is a graph showing the comparison of current values between the three variations of immersion time.

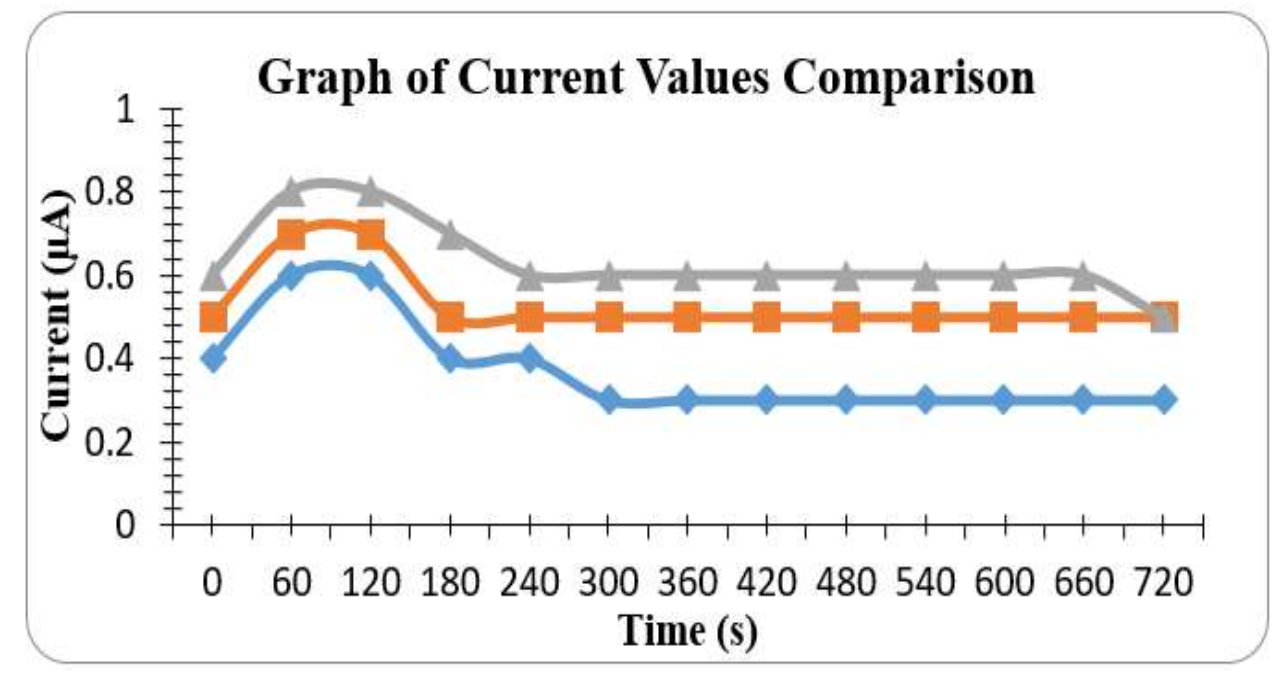

Figure 10. The Results of The Third Data Collection Variation

Figure 10 shows the comparison of the current value $(\mu \mathrm{A})$ of the three immersion time variations. It can be observed that at 60 and 120 seconds, the highest current value is obtained when compared to other times, this is because this study uses the maximum absorbing light and excitation dye from dssc lies at the time. Maximum absorbing and excitation dye power at a certain time is obtained because of several factors including the thickness of the $\mathrm{TiO}_{2}$ layer, the concentration of the solution and the electrolyte composition. So not all studies will get maximum absorption at the same time. After that, the slow decline is due to electrolyte degradation due to exposure to light and heat of 500 watts of halogen lamps as a light source which has implications for the performance of Dye Sensitized Solar Cells.

\section{CONCLUSION}

Through the research conducted, the results obtained the highest current value on the effect of immersion time of purple leaf extract produced from dye sensitized solar cells were found in the 36 hour immersion variation with the highest current value of $0.8 \mu \mathrm{A}$ followed by 24 hours of immersion time variation with the highest current value. $0.7 \mu \mathrm{A}$, and for the variation of immersion at 12 hours the lowest current value was obtained, with a current value of 0.6 $\mu \mathrm{A}$. The results of the current value prove that the variation of immersion duration affects the amount of current value capable of producing dye sensitized solar cells with purple leaf extract.

\section{REFERENCES}

Andargie, W., \& Worku, D. (2016). Dye-sensitized solar cells using natural dye as lightharvesting materials extracted from Acanthus sennii chiovenda fl ower and Euphorbia cotinifolia leaf. Journal of Science: Advanced Materials and Devices, 1(4), 488-494. 
https://doi.org/10.1016/j.jsamd.2016.10.003

Bennett, N., Chen, B., Upadhayaya, H., Raghava, K., Kumar, D. K., Kr, J., \& Sadhu, V. (2020). Functionalized metal oxide nanoparticles for efficient dye-sensitized solar cells ( DSSCs ): A review. Materials Science for Energy Technologies, 3, 472-481. https://doi.org/10.1016/j.mset.2020.03.003

Dahyunir, D., Tjiauw, S. L., \& Hermansyah, A. (2016). Dye sensitized solar cells (dssc) dengan sensitiser dye alami daun pandan, akar kunyit dan biji beras merah (black rice). Jurnal IImu Fisika, 8(1), 1-8.

Hardeli., Zainul, R., \& Isara, L. P. (2019). Preparation of Dye Sensitized Solar Cell ( DSSC ) using anthocyanin color dyes from jengkol shell ( Pithecellobium lobatum Benth .) by the gallate acid copigmentation Preparation of Dye Sensitized Solar Cell ( DSSC ) using anthocyanin color dyes from jeng. International Conference on Reseach and Learning of Physics, (1185). https://doi.org/10.1088/1742-6596/1185/1/012021

Irwan, A., Iswadi., \& Hernawati. (2016). Studi awal fabrikasi dye sensitized solar cell (dssc) dengan menggunakan ekstrak buah dan daun sirsak (Annona Muricata I) sebagai fotosensitizer. JFT, 3(1), 1-13.

Kabir, F., Bhuiyan, M. M. H., Manir, M. S., Rahaman, M. S., Khan, M. A., \& Ikegami, T. (2019). Development of dye-sensitized solar cell based on combination of natural dyes extracted from Malabar spinach and red spinach. Results in Physics, 14, 102474. https://doi.org/10.1016/j.rinp.2019.102474

Kong, M., Kang, C. H., Alkhazragi, O., Sun, X., Guo, Y., Sait, M., \& Ooi, B. S. (2020). Survey of energy-autonomous solar cell receivers for satellite - air - ground - ocean optical wireless communication. Progress in Quantum Electronics, 74, 100300. https://doi.org/10.1016/j.pquantelec.2020.100300

Lu, L., Ya, M. E., Anuar, M. S., Chen, G., Othman, M. H., \& Iskandar, A. N. (2020). Thermal analysis of a portable DSSC mini greenhouse for botanical drugs cultivation. Energy Reports, 6, 238-253. https://doi.org/10.1016/j.egyr.2019.12.025

Oh, W., Liu, Y., \& Areerob, Y. (2021). A novel fabrication of organic-inorganic hybridized Graphene- La 2 CrFeW 6 nanocomposite and its improved photovoltaic performance in DSSCs. Journal of Science: Advanced Materials and Devices, 6(2), 271-279. https://doi.org/10.1016/j.jsamd.2021.02.008

Ossai, A. N., Ezike, S. C., Timtere, P., \& Ahmed, A. D. (2021). Enhanced photovoltaic performance of dye-sensitized solar cells-based Carica papaya leaf and black cherry fruit co-sensitizers. Chemical Physics Impact, 2, 100024. 
Immersion Duration Effect of Purple Leaf Extract (Graptophyllum Pictum) on DSSC

https://doi.org/10.1016/j.chphi.2021.100024

Reny, S. (2018). Uji Aktivitas Antioksidan Infusa Daun Ungu Dengan Metoda DPPH (1,1diphenil- 2-picrylhidrazil). Jurnal Katalisator, 3(2), 153-161.

Roslan, N., Ya, M. E., Radzi, M. A. M., Hashimoto, Y., Jamaludin, D., \& Chen, G. (2018). Dye Sensitized Solar Cell ( DSSC) greenhouse shading: New insights for solar radiation manipulation. Renewable and Sustainable Energy Reviews, 92, 171-186. https://doi.org/10.1016/j.rser.2018.04.095

Sagita, R., \& Budi, P. S. (2014). Rancang bangun alat kontrol pengisian aki untuk mobil listrik menggunakan energi sel surya dengan metode sequensial. Jurnal Teknik Waktu, 12, 61-66.

Syafinar, R., Gomesh, N., Irwanto, M., Fareq, M., \& Irwan, Y. M. (2015). Potential of Purple Cabbage , Coffee, Blueberry and Turmeric as Nature Based Dyes for Dye Sensitized Solar Cell ( DSSC ). In Energy Procedia, 79. https://doi.org/10.1016/j.egypro.2015.11.569

Wang, Z., Zhang, X., \& Rezazadeh, A. (2021). Hydrogen fuel and electricity generation from a new hybrid energy system based on wind and solar energies and alkaline fuel cell. Energy Reports, 7, 2594-2604. https://doi.org/10.1016/j.egyr.2021.04.060 